\title{
Econder
}

\author{
International Academic Journal
}

[Econder], 2021, 5 (1): 6/32

Para ve Maliye Politikalarının Ekonomik Büyüme Üzerindeki Etkileri: Irak Ekonomisi Üzerine Ampirik Bir Çalışma

$\&$

Effects of Monetary and Fiscal Policies on Economic Growth: An Empirical Study On The Iraqi Economy

\begin{tabular}{|c||}
\hline \hline Yaşar KÖSE \\
Doç.Dr.,Türk Hava Kurumu Üniversitesi, İşletme Fakültesi, İşletme Bölümü \\
Assoc.Prof.Dr., University of Turkish Aeronautical Association, Faculty of \\
Business Administration, Department of Business Administration \\
ykose@thk.edu.tr \\
Orcid ID: 0000-0003-0073-2095 \\
Sakar ALI \\
Dr., Türk Hava Kurumu Üniversitesi SBE, İşletme ABD \\
Dr, University of Turkish Aeronautical Association, Institu of Social \\
Science, Business \\
sacarkader@yahoo.com \\
Orcid ID: 0000-0003-0073-2095
\end{tabular}

Makale Bilgisi / Article Information

Makale Türü / Article Types : Araştırma Makalesi / Research Article

Geliş Tarihi / Received $\quad: 17.02 .2021$

Kabul Tarihi / Accepted $\quad: 30.04 .2021$

Yayın Tarihi / Published : $\quad$ 30.06.2021

Yayın Sezonu : Haziran

Pub Date Season : June

Cilt / Volume: 5 Say1 - Issue: 1 Sayfa / Pages: 6-32

Atıf/Cite as: Köse, Y , Alı, S . (2021). Effects of Monetary and Fiscal Policies on Economic Growth: An Empirical Study On The Iraqi Economy . Econder International Academic Journal , 5 (1) , 6-32 . DOI: 10.35342/econder.881909 İntihal /Plagiarism: Bu makale, en az iki hakem tarafından incelenmiş ve intihal içermediği teyit edilmiştir. / This article has been reviewed by at least two referees and scanned via a plagiarism software. 
Copyright (c) Published by Hayrettin KESGINGÖZ- KSU University, Kahramanmaras, 46000, Turkey. All rights reserved.

Para ve Maliye Politikalarının Ekonomik Büyüme Üzerindeki Etkileri: Irak Ekonomisi Üzerine Ampirik Bir Çalışma

\title{
Öz
}

Çalışmanın amacı, para ve maliye politikalarının Irak'taki ekonomik büyüme üzerindeki etkilerini açılamaktır. Bağımlı değişken ekonomik büyüme oranıdır ve bağımsız değişkenler döviz kuru, enflasyon, parasal bir araç olarak M2, mali araçlar olarak kamu borcu, kamu harcamaları ve devlet geliridir. Veriler Irak Merkez Bankası'ndan alınmıştır ve 2005-2019 dönemini kapsamaktadır. ARDL Bound Test ve OLS, sırasıyla para ve maliye politikalarının büyüme üzerindeki etkilerini tahmin etmek için kullanılmıştır. Para politikası açısından,;döviz kurunun ekonomik büyümeye zarar verdiğini, enflasyon ve para arzının ise ekonomik büyümeyi olumlu etkilediğini ortaya koyulmuştur. Maliye politikası açısından bakıldığında, devlet borçlarının ve devlet harcamalarının büyüme üzerindeki etkileri olumsuz, devlet gelirleri ise olumlu olduğu belirlenmiştir.

Anahtar Kelimeler: Ekonomik Büyüme, Maliye Politikası, Para Politikası, Enflasyon, Devlet Gelir ve Harcamaları

\section{Effects of Monetary and Fiscal Policies on Economic Growth: An Empirical Study on The Iraqi Economy}

\begin{abstract}
The purpose of the study is to explain the effects of monetary and fiscal policies on economic growth in Iraq. The dependent variable is the economic growth rate, and independent ones are exchange rate, inflation, M2 as a monetary instrument, while public debt, public expenditure, and government revenue are as fiscal instruments. The data were obtained from the Central Bank of Iraq and covers the period of 2005-2019. ARDL Bound Test and OLS were used to estimate the effects of monetary and fiscal policies on growth respectively. As for monetary policy, the results revealed that the exchange rate harms economic growth, while inflation and money supply positively affect economic growth. In terms of fiscal policy, the effects of government debt and government spending on growth seemed to be negative, while government revenues seemed to be positive.
\end{abstract}

Keywords: Economic Growth, Fiscal policy, Monetary Policy, Inflation, Government Revenue, and Spending.

\section{Introduction}

Economic growth is the most important issue, especially in developing countries, as it is considered an indicator and a mirror reflecting the general economic situation. There are many inconsistencies and intertwining economic problems that the economist seeks to overcome, the best of which is fiscal and monetary policy.

The fiscal policy attains its place among other policies because of its merit in achieving national economic goals through its tools included in the most important economic management tools. But in fact, this policy was absent from the economic scene for a long time, until it was reborn, 
especially after the Great Depression in 1929, thanks to the contribution of the great economist Keynes.. John Maynard Keynes demanded the state's need to intervene in economic activity to move from the pattern of the guardian state to that of the intervening state.

The monetary policy represents the monetary aspect of macroeconomic policies. This requires a high degree of coordination with other economic policy tools, especially with fiscal policy. They are the most used ones preferred in various countries (regardless of the size or type of their economic systems) to achieve economic growth. These policies lead to improving the population's standard of living, providing employment opportunities, and reducing unemployment, as well as stimulating economic performance through increased investment and production.

In that context; the study aims to examine if the fiscal and monetary policies affect the growth in Iraq or not. The conceptual structure of the monetary and fiscal policies was argued in the first part of this study. In the second part of the study, the literature was reviewed. Our examination approach has been stated in the fourth chapter, and the outcomes and their related comments are in the fifth and sixth chapters, respectively. All of the suggestions for the people in charge and prospective studies have been discussed in the final section.

\section{Conceptual Framework}

Under any regime, the purpose of economic activity is to meet the needs of society. People earn profits, consume, save, and invest. Society pays taxes, and also accordingly the states are supported by all of them. Therefore, money flows, and the different parts' interrelationships can be seen in an economy (Trotman1996:6).

The interaction between the general and the special financial policy, fiscal and monetary policies, is always in a direction that results in the increment in their influences on incomes, interest rates, inflation, exchange rate expenditures, and the rest of the prominent economical earnings. Without considering all possible strategies, we are unable to foretell the impacts of one type. If we are to reach our wanted economic ends of inside and outside equilibrium in the global scale, the related people in charge shall use the special form of financial policy to make an impact on the various aspects of paying methods, such as value, amount and the presence of money. This procedure has been devised to manipulate the money sums in the economy, by acclimatizing the sources of money, and/or the rate of appeal. For this reason, this policy is always being followed by several nations, which acts as an organizer for ensuring the rise and the improvement of the economy overtime. Historically, this fixed plan and the way of joining of money effects in creating the economy returns to Adams 
Smith's era, which was developed later by those economists who were studying monetary (Bain and Howells, 2003:14-15).

Monetary economics is a branch of economics based on the economy's capital and monetary ties. It concentrates on the links between money and prices, output, and employment and so is the development of macroeconomics. The relationship between the rate of growth of the supply of money and the rate of inflation has been of particular concern to monetary economists. Some countries have taken many important institutional decisions regarding monetary policy works. One of the most important goals of monetary policy is to know what governments or the central bank can do to improve the way monetary instruments are dealt with to avoid harming the real economy's performance (Ufoeze et al., 2018:2).

The aim of the fiscal policy, is to go through the intentional actions of the government in expenditures and payable taxes to orient the macroeconomic factors in the intended path. It contains the stable escalation of the economy, increase in the employment rate, and the decrease in inflation. Due to this, the general policy is planning to decrease the variations and to fix the status of the economy (Ogbole et al., 2011:3-4). If the government's expenditure grows or the taxation collapse, the economy would fall and the business status would become unsuccessful, and vice versa (Dornbusch et al., 2011). So, fiscal policy, as an element of economic policy, contributes to the implementation of the economic program and plays an active role in achieving it, provides theories and solutions, confronts strategies, and makes choices and decisions as well as actions to achieve them (Jeffrey, 2019:4). Hemming et al. (2003) suggest that fiscal policy's effect on economic activity may also depend on structural factors such as internal and external lags, considerations or factors of the political economy, and level of growth.

Despite its simplicity, the exchange rate, which means "the process of exchanging one currency for another," leaves significant impacts, both negative and positive, on the economy when it changes up or down without planning (Eichenbaum et al., 2017). The difficulty lies in how the economy's sustainability affects the outside world and not the other way around - the less durable the economy, the greater control over the outside world via the exchange rate gateway. An unstable economy will need to engage with the outside world to meet its needs (Bernanke, et al., 2008). They stressed that the decline in currency exchange rates does not indicate economic weakness. On this basis, any country can reduce the exchange rate for increasing economic activity at the local and global levels while revitalizing its economy by increasing production and increasing its exports (Riyadh et al., 2017). In some countries, especially developed countries, there is a causal relationship with economic growth. Sometimes, there is a two-way causal relationship, which means that exchange rate fluctuations affect economic growth, and economic growth influences the exchange rate volatility (Korkmaz, 2013:2-3).

Econder|

ECONDER International Academic Journal [Issn: 2602-3806]
Cilt / Vol: 5, Say1/Issue: 1, 2021 
One of the most important considerations in the formation of the economy and the financial policies, is the correspondence between the economic surge and the inflation, though we have not yet reached the precise form of this interaction. A moving interaction of the mentioned factors are present both in the developed and developing nations. According to the properties of the region, i.e. earning money from investments or not, the influence of the protuberance alters within different countries. A minus dependence is generally provided between the protuberance and growth, particularly in promoted economies (Foluso et al., 2017). With regards to the developing economies, the growth could improve, in case of the reduced protuberance (Mallik and Chowdhury, 2001; Rapach, 2003; Ben-habib and Spiegel, 2009; Kasim, 2012). According to Wai (1995), another cause for the unpredictable correspondence between the protuberance and the rise of economy, is that their relation is in fact negligible.

The relationship between economic growth and inflation is of great importance in the economy and monetary policy composition. However, the exact relationship between them has not been determined. There is a dynamic relationship between growth and inflation in both developing and developed countries. The effect of inflation on economic growth varies from one country to another, depending on the characteristics of the states as rentier or productive. In general, there is overwhelming support for a negative relationship between inflation and growth, especially in advanced economies (Foluso et al., 2017). As for developing economies, low inflation positively affects growth (Mallik and Chowdhury, 2001; Rapach, 2003; Benhabib and Spiegel, 2009; Kasim, 2012). There is another reason for the causal relationship between inflation and economic growth. Wai (1995) concluded that there is no significant relationship between them.

A vital factor in the macroscopic scale of the economy, is the stockpiling of money, which impacts the rise in the economy through guaranteeing the maintenance of economic chores, regardless of the type of the economical section (i.e. private or state) (Prasert et all., 2015).

A money supply can have a positive effect (Ogunmuyiwa and Ekone, 2010). The monetarists claim that the supply of money is an instrument that gives economic growth a boost based on an unforeseen rise in the stock of money (Jawaid et al., 2011). However, the supporters of the Maynard Keynes theories claim that this effect is of much less importance (Twinoburyo and Odhiambo, 2017). All results indicate that the money supply, negatively or positively, depends on the amount of liquidity offered and the central bank's monetary policy to achieve equilibrium.

Public finance investigators and the great scale economical patterns always worry about the coincidence between the rise in the economy and the government's expenditure, and they emphasize the expenditure impacts on the escalation of the economy. Whether the increasing government's 
expenditure help or ruin the escalation in the economy, is a fundamental question to be responded in the growth theory.

Neither the theoretical nor the experimental investigations are able to give a determinant result, without being antithesis. Although the theories of Keynesian and Wagner are in the side with the direct relation between the people's expenditures and the escalation in the economy, laissez-faire supporters are on the opposite side, claiming that this has a negative side by providing no opportunities for developing. The latter view indicates that the total efficiency of the economy will lessen due to the people's expenditure (Nurudeen and Usman, 2010). The decrease in the sectional dissimilations and the improvement of the social dorsal due to the act of the public spending, is making the foundation of the escalation in the economy, according to Josaphat and Oliver (2000). This spending could serve as a merit for the economic escalation, if being outlay in great scales.

Catastrophes such as wars and pandemics, result in the financial breakdowns, and recently several countries are asking the people to pay more for their debts. Due to this, this topic has now become a controversial concept for studying, to examine the influences on the escalation in the economy, particularly after the attempts of Reinhart and Rogoff (2010), which summed up that public debt harms economic growth when it reaches more than $90 \%$ of the GDP (Kumar and Woo, 2015. Countries that resort to public debt for short periods have a positive effect because most short-term debts are paid quickly (Elmendorf and Mankiw, 1999). The direct negative effect of growth on public debt in high-debt countries is compounded by an increase in the long-term real interest rate which in turn lowers interestsensitive demand and contributes to a further rise in the public debt ratio. Public debt has negative and positive effects. First, the debt period is long or short term. Second, the purpose of the debt is for investment, operating expenses, or emergency purposes (Jacobs et al., 2019).

Revenues include two types, the first is revenues collected through taxes and fees, and the second is that they are obtained from natural resources. It is most likely that tax receipts are the most important source of general government revenues in most countries. However, government receipts from non-tax sources call for examination. Non-tax revenues from foreign aid and oil resources contribute to the system's stability in both developed countries and developing countries (Mourre and Reut, 2018). Tax collection in developed or developing countries lacks mechanisms for implementing taxes that help them develop infrastructure and contribute to economic growth. Thus, taxes have one way to generate income in any government to meet citizens' needs. The lack of correct collection methods leads to lower economic growth (Abiola and Asiweh, 2018). In developed countries, taxation is significant because it is one of the important revenues at the core of their development. Taxes are imposed according to sophisticated mechanisms and policies to reach the largest possible revenue 
contributing to economic growth as declared by Morrison (2009), the matter is how these revenues are used to contribute to growth.

\section{Literature Review}

Since the 1970s, monetary policy has had some benefits over fiscal policy and that is because of the lack of political influence, as defined by the central bank. Moreover, fiscal policy also has significant impacts on the economy, particularly in tax and non-tax revenue collection and spending control.

The escalation in the economy will have more positive outcomes, when it comes to the relation between the special and general type of financial policy, according to some researches (Friedman and Meiselman, 1963; Elliott, 1975; Rahman, 2005; Senbett, 2011). For the equilibrium of the economy in macroscopic scales, the special policy of finance is more efficient. However, by referencing to the researches done by (Ajisafe and Folorunso, 2002; Adefeso and Mobolaji, 2010; Ajisafe and Folorunso, 2002; Chowdhury, 1986. Mohammad, et al., 2009), this balance is more related to the expenditures of the government and tax variations than this kind of financial policy.

A scheme has been conducted in Nigeria by Tule et al. (2020), to display the coordination between these financial policies from 2003 to 2017. According to the conclusion, these financial policies boost the growth in the economy, regardless of putting the prices in the peril of being harmed. Thereafter, if we utilize the general kind of financial policy in major projects, the economy would be improved and fasten any activities which is related to the requirement of private section of money profits, in the economy.

Alkasasbeh (2018) found that the relationship between fiscal policy and economic growth is not clear. There is a positive relationship in some cases, while there may be a negative relationship in others. These cases are related to the economic reality of the country. Cyrus (2014) used the (VAR) model in Kenya and found that fiscal policy has a significant impact on economic growth, unlike monetary shocks, which are not significant in Kenya.

With regards to the Jordan, Mugableh (2019) stated that there is a same emotion and interest between the general wealth and the escalation in the economy, which proved to be useful. They extracted the corresponding information from 1978 to 2017, and self-distributed lag models and also the error correction model of Vector has been modified. They obtained that, in the long term, the spending of the government could be beneficial for the economy to level up. More clues for this topic have been investigated by Hasnul (2015) in Malaysia from 1970 to 2014. Accordingly, this spending can be categorized into two section, operating and development spending, and

$$
\text { Bconder } \quad \begin{gathered}
\text { ECONDER } \\
\text { International Academic Journal }
\end{gathered}
$$


these results are the outcomes of the OLS. Furthermore, he uncovered the minus correlation of spending and surge in the economy. In this idea, the small improvement in the economy is a result of excessive financial care on residency and the part which is related to the development. It is also interesting to note that other aspects such as education, defense, health care and costs of other activities have no contribution.

According to the study conducted by Bayrak (2019) on Turkey, the optimal value of defense expenditure, which triggers the growth, is $2.5 \%$ of GDP. In other research employed by Bayrak (2020), it was found that the optimal value of public expenditures for Turkey, Bulgaria, and Tunisia seemed to be $23.03 \%, 22.78 \%$, and $21.77 \%$, respectively.

There could be some periods, in which, according to Onuorah and Akujuobi (2012), the escalation of the economy could fluctuate, and the outside factors act in an antithesis way in the GDP. If we consider Nigeria, for instance, the outcomes of the study exhibit that the expenditure of the population and the escalation in the economy have no statistical correlation. By using the information from 10 selected countries from Central and Eastern Europe from 1995 to 2015 Lupu et al. (2018) showed that in the autoregressive distributed lag (ARDL) model, the coordination between various types of the people's expenditures and the rise in the economy can be uncovered. Moreover, it has found out that if we invest on the education and health care, it is beneficial for the economy, and on the other hand, too much spending on security services, foreign affairs, public services, and social welfare is harmful. However, according to Nyasha and Odhiambo (2019), no precise relation between the government's expenditure and the surge in the economy. Despite this, the process of measurement is directed upward. The same distributed self-regression model (ARDL) has been conducted by Ali et al (2013) from 1972 to 2009 to detect any impacts of the spending of the population on the economy, and the result was positive.

The correlation between the total government's money lent to the people and the variation of the rise in the real GDP was displayed by Reinhart and Rogoff (2010), which was negative in the long term, particularly for the time that this relationship makes up to the 90 percent of GDP. Another study was performed by Ahlborn and Schweickert (2016), which contained three country clusters and their economical organizers were thoroughly various, namely liberal, continental, and Nordic. The outcome was that in the continental system, the proportion of rise is more remarkable than the liberal one, and it causes an abate in the influences of the debts of the people. This type of debt proved to has more goodness than harm. In the Nordic case, however, things are quite different. The correlation is not linear, and this results in a collapse in the GDP to nearly 60 percent of the peoples debt. By utilizing the yearly information in the period of 1961 to 2013, Puig (2013) examined this pay offs of the population on the escalation in the economy, in both short and long terms. With regards to the short term

Cilt / Vol: 5, Sayı/Issue: 1 , 2021 
outcome, according to that particular country, there may be a positive in uence, while in the long term it is a down side for the participants of the EA.

Gurdal et al. (2020) made use of the yearly information from 1980 to 2016, in order to find the coordination between the three factors of the population's regular fee, government's expenditure and the rise in the economy, for the United Kingdom, Germany, the United States of America, Italy, Japan, and France. According to the results, those countries that used economic conjuncture of G7 for their taxes, are mightier in their finance and have a higher chance to reach their desired ends. In the case of Nigeria, Cornelius et al. (2016) studied the factors which had impacts on this nation's economy, such as the regular fee of petroleum, non-oil products, taxes, according to the least-squares of multiple regression models. With regards to the outcome, although corporate income tax and the surge were not prominent in terms of any correlations, incomes from non-oil products played a remarkable role. The method of Ordinay Least Squares (OLS) regression has been conducted by Joseph et al. (2020), by using the information from 1981 to 2018, to test any similarity between the government's incomes and improvements in the economy, and it turned out that this income plus value ddded tax (VAT), which is particularly for the federal, are merits for this improvement.

Some other deductions were discovered by Omodero (2019) from 2009 to 2018, with respect to the general type of financial policy in Nigeria and Ghana. For the prior, M2 has a minute impact on GDP; M3 is a benefit for GDP. Private section's credits (CPS) were also a merit for GDP. With regards to the former, M2 is a plus point; M3 is a significant harm, CPS is a relatively advantage for GDP. So in order to boost the economy in both nations, these general policies shall be decided by the people in charge, and also M2 and CPS should have a more active role, since they are responsible for the rise in the economy, that as a result leads to an abundant status of occupations and production. By using the information from the past 3 decades, Hameed and Amen (2011) considered how useful this policy can be, in terms of the regression analysis technique, and according to the results, there is a coordination between the two mentioned aspects in Pakistan. Moreover, if the amount of money in hoards increases, it highly benefits the situation of producing domestic items.

Another case in Tanzania, from the information extracted in a period from 1990 to 2011, by Kasidi and Mwakanemela (2013) was performed to reveal any relations between the protuberance and the rise in the economy, and none was observed. But this protuberance could harm the improvement of the economy, which is also not valid for the long term. However, in the Nigeria, based on a study by Osuala and Onyeike (2013), this is a merit, but there is no other great factor other than that. Another researcher, Hasanov (2011), studied any impacts of the protuberance and the rise in the economy 
from 2000 to 2009. Based on that, in Azerbaijan's economy, protuberance has a non-linear coordination with the rise in the economy, and this protuberance is rising to 13 percent in GDP levels. If this number grows up, it could be a harm, while any percentages below 13 are highly beneficial on the rise of the GDP.

In case of the influences of the financial stockpiles M2 on the GDP in Pakistan, Ihsan and Anjum's paper (2013) is an examination for this, from 2000 to 2011, and it had negative impacts. Some other models like a formal advanced training course (ARC) model, and a nominal ARC model of the money supply, have been created by Dai and Wu (2013), according to the Solow's model of growth. Money is the cure for the economy to rise and relieve, based on their outcomes. Researchers like Ayodeji and Oluwole (2018), made use of the Jo- hansen Co-Integration test, and Engle Granger Co-Integration test, to display the correlation between the speed of substitution and the rise in the economy for the long times, and their source of information was from 1981 to 2016, and among their factors were the substitution and desired rate, along with the money hoards and the interchangeability of assets and money. For the GDP of the Nigeria, substitution rate and the money hoards were benefits, though not relevant. In China, for various states, this study revealed real exchange rate in the rise in the economy and how these factors approach together, conducted by Chen (2012). They were active panel information obtained from 28 Chinese provinces from 1992 to 2008, and the outcomes showed a merit. For Malaysia, Kogid et al. (2012) studied the impacts of the speed of the substitution by performing data from time series, in the period of 1971 to 2009. Regardless of the type of the rate (nominal and real), the in uence does not change. If we also use the long-term ARDL test, we gain advantages, but for the ECM, the results are by chance for the rise in the economy. The last coming output for Malaysia, is that the special kind of financial policy has benefits for boosting the economy.

\section{Methodology}

Time-series data analysis methods have been implemented in this study. This type of data is comprised of a set of end-to-end data points which provides the data about a given variable in every unit of time which is defined based on the features of the variable itself. It could be gathered in a year, 4 month, month, week, or even day. In the case of the economical information, we can find any data related to how often the shocks are maintained, how readable is the rate of change, how probable is the sudden fluctuations over the particular period, and whether they tend to move slowly and vaguely, with respect to the other factors. Many applications for them can be found, for instance social sciences, finance, economics, physical sciences, and epidemiology (Shrestha and Bhatta .2018:72).

Cilt / Vol: 5, Sayı/Issue: 1, 2021 
Sometimes, the time series data is in contrast with our postulates of the conventional statistical methods. So researchers use time series analysis, which are that information from the previous model that need a unique set of instruments and procedures, and these models have various types, like ARDL.

In the ARDL approach, we combine factors together, in order to examine any correlation between them, for a long period, and this has a superiority over the classical version of cointegration tests (Nkoro and Uko, 2016). The initial one is that it is independent of the kind of the series $(\mathrm{I}(0)$ or I(1)). Next, the error correction model is unlimited (UECM) and we can obtain them by only using a single linear transformation of the ARDL bounds testing. This model is active, regardless of the length of the time. The final advantage, is that it is the most appropriate method for tiny samples (Cetin et al., 2015).

Among the various linear methods for estimating the model parameters (regression parameters), the Ordinary Least Squares (OLS) method which is known as the most widely used and dominant method due to its desirable properties (of course, when the assumptions of this method are met). This method is believed to be established by the famous German mathematician Karl Friedrich Goss. OLS tries to fit the best regression line between the observed data and the data predicted by the model by minimizing the sum of squares of perturbation sentences. This principle is known as the principle of least squares (Zdaniuk. 2014). In this study, the variables used were presented in Table 1.

Table 1: Variables and Definitions

\begin{tabular}{|c|c|c|c|c|}
\hline \multicolumn{2}{|c|}{ Variables } & Definition of Variables & $\begin{array}{c}\text { Expected } \\
\text { Signes }\end{array}$ & Resource \\
\hline $\begin{array}{l}\text { Dependent } \\
\text { Variable }\end{array}$ & GDPR & GDP Growth Rate & & \multirow{7}{*}{$\begin{array}{c}\text { Central Bank } \\
\text { of Iraq }\end{array}$} \\
\hline \multirow{6}{*}{$\begin{array}{l}\text { Independent } \\
\text { Variables }\end{array}$} & EXCR & Exchange Rate & + & \\
\hline & M2R & M2 Money Supply & + & \\
\hline & INFR & Inflation Rate & - & \\
\hline & PDEPR & Public Debt Rate & - & \\
\hline & GREVR & Government Revenue & + & \\
\hline & GEXPR & Government Expenditure & + & \\
\hline
\end{tabular}

The dependent variable of the study is the GDP. In this study quarterly GDP rate was included as a dependent variable. Independent variables are exchange rate, M2 money supply, inflation rate, public debt, government revenue, and government expenditure respectively. M2, public 
debt, government revenue, and government expenditure was calculated to be the quarterly ratio to avoid the effect of inflation.

To measure the effects of monetary and fiscal policies on the growth respectively, the first and second equation below was established and estimated. Variables were estimated using the OLS method. The model is shown in equation 1 and 2;

$$
\begin{array}{ll}
G D P R_{t}=\beta_{0}+\beta_{1} E X C R_{t}+\beta_{2} M 2 R_{t}+\beta_{3} I N F R_{t}+e_{t} & \beta_{1}, \beta_{3}<0 \\
G D P R_{t}=\beta_{0}+\beta_{1} P D E P R_{t}+\beta_{2} G R E V R_{t}+\beta_{3} G E X P R_{t}+e_{t} & \beta_{1}, \beta 3<0
\end{array}
$$

In the following parts of the study, firstly ADF and PP Unit Root Tests results will be given. Long-term and Short-term Coefficient Estimations will then be presented. Lastly, other estimation results will be respectively shown.

\section{Findings}

To apply time series analysis, all series included in the analysis must be stationary. Because both $R^{2}$ and $t$ statistics may present misleading results due to the risk of spurious regression in series where stationarity cannot be achieved (Newbold and, Granger 1974; Gujarati and Porter, 2009). The most commonly used method for determining the stationarity of the series is unit root tests (Gujarati, 1999:718-719). In this analysis, all three models of ADF and PP Unit Root Tests (without constant, with constant, with constant and trend) are used. The level values of the unit root tests of the series are presented in Table 1 and the first difference values are presented in Table 2.

\begin{tabular}{|c|c|c|c|c|c|c|}
\hline \multirow[b]{2}{*}{ Variables } & \multicolumn{3}{|c|}{ Augmented Dicky Fuller (ADF) } & \multicolumn{3}{|c|}{ Phillips Perron (PP) } \\
\hline & None & Constant & $\begin{array}{c}\text { Constant } \\
\text { and Trend }\end{array}$ & None & Constant & $\begin{array}{c}\text { Constant } \\
\text { and Trend }\end{array}$ \\
\hline GDPR & $-2.540897^{* *}$ & $\begin{array}{c}- \\
4.418075^{* * *}\end{array}$ & $\begin{array}{c}- \\
4.497518^{* * *}\end{array}$ & $-2.531990^{* *}$ & $\begin{array}{c}- \\
4.625514^{* * *}\end{array}$ & $\begin{array}{c}- \\
4.686649^{* * *}\end{array}$ \\
\hline EXCR & -1.364468 & $-2.821281^{*}$ & -2.137119 & -1.460283 & -2.480740 & -1.637959 \\
\hline \multicolumn{7}{|c|}{ Table1: Continue } \\
\hline M2R & -1.394134 & -2.223509 & $\begin{array}{c}- \\
7.423555^{* * *}\end{array}$ & $\begin{array}{c}- \\
5.116626^{* * *}\end{array}$ & $\begin{array}{c}- \\
6.455326^{* * *}\end{array}$ & $\begin{array}{c}- \\
7.438295^{* * *}\end{array}$ \\
\hline INFR & $-2.298521^{* *}$ & -1.954169 & $\begin{array}{c}- \\
12.51456^{* * *}\end{array}$ & $-2.262893^{* *}$ & -2.078373 & -2.034147 \\
\hline PDEPR & $-2.142762^{*}$ & $-2.238098^{*}$ & -2.185415 & $\begin{array}{c}- \\
6.336129^{* * *} \\
\end{array}$ & $\begin{array}{c}- \\
6.481236^{* * *} \\
\end{array}$ & $\begin{array}{c}- \\
6.462768^{* * *}\end{array}$ \\
\hline GREVR & $\begin{array}{c}- \\
3.713508^{* * *}\end{array}$ & $\begin{array}{c}- \\
3.684082^{* * *} \\
\end{array}$ & $-3.691988^{* *}$ & $\begin{array}{c}- \\
8.686263^{* * *}\end{array}$ & $\begin{array}{c}- \\
8.634883^{* * *}\end{array}$ & $\begin{array}{c}- \\
8.611613^{* * *}\end{array}$ \\
\hline GEXPR & $-2.127913^{* *}$ & $-2.610574^{*}$ & -2.644432 & $\begin{array}{c}- \\
10.48360^{* * *}\end{array}$ & $\begin{array}{c}- \\
10.70618^{* * *}\end{array}$ & $\begin{array}{c}- \\
11.50254^{* * *}\end{array}$ \\
\hline \multicolumn{7}{|c|}{ MacKinnon Critical Values } \\
\hline$\% 1$ & -2.604746 & -3.546099 & -4.121303 & -2.604746 & -3.546099 & -4.121303 \\
\hline
\end{tabular}

Table 1. Unit Root Tests (Level)

ECONDER

International Academic Journal

[Issn: 2602-3806]
Cilt / Vol: 5,

Sayı/Issue: 1, 2021 


\begin{tabular}{|c|c|c|c|c|c|c|}
\hline $\mathbf{0 5}$ & -1.946447 & -2.911730 & -3.487845 & -1.946447 & -2.911730 & -3.487845 \\
\hline $\mathbf{0 1 0}$ & -1.613238 & -2.503551 & -3.172314 & -1.613238 & -2.593551 & -3.172314 \\
\hline
\end{tabular}

Note: ${ }^{*}, * * * *$ signs represent $.10, .05$. and .01 significance level of $(\alpha)$ critical values respectively.

Table 2. Unit Root Tests (1 ${ }^{\text {st }}$ Difference)

\begin{tabular}{|c|c|c|c|c|c|c|}
\hline \multirow[b]{2}{*}{$\begin{array}{l}\text { Variab } \\
\text { les }\end{array}$} & \multicolumn{3}{|c|}{$\begin{array}{c}\text { Augmented Dicky Fuller } \\
\text { (ADF) }\end{array}$} & \multicolumn{3}{|c|}{ Phillips Perron (PP) } \\
\hline & None & $\begin{array}{c}\text { Consta } \\
\text { nt }\end{array}$ & $\begin{array}{c}\text { Consta } \\
\text { nt and } \\
\text { Trend } \\
\end{array}$ & None & $\begin{array}{c}\text { Consta } \\
\text { nt }\end{array}$ & $\begin{array}{c}\text { Consta } \\
\text { nt and } \\
\text { Trend } \\
\end{array}$ \\
\hline GDPR & $\begin{array}{c}- \\
10.5435 \\
1^{* * *}\end{array}$ & $\begin{array}{c}- \\
10.4424 \\
9^{* * *}\end{array}$ & $\begin{array}{c}- \\
10.3220 \\
5^{* * *}\end{array}$ & $\begin{array}{c}- \\
10.6316 \\
5^{* * *}\end{array}$ & $\begin{array}{c}- \\
10.5278 \\
8^{* * *}\end{array}$ & $\begin{array}{c}- \\
10.4077 \\
6^{* * *}\end{array}$ \\
\hline EXCR & $\begin{array}{c}- \\
4.74259 \\
1^{* * *}\end{array}$ & $\begin{array}{c}- \\
4.89186 \\
4^{* * *} \\
\end{array}$ & $\begin{array}{c}- \\
5.27679 \\
4^{* * *}\end{array}$ & $\begin{array}{c}- \\
4.71937 \\
6^{* * *} \\
\end{array}$ & $\begin{array}{c}- \\
4.88000 \\
0^{* * *}\end{array}$ & $\begin{array}{c}- \\
5.24385 \\
3^{* * *}\end{array}$ \\
\hline M2R & $\begin{array}{c}- \\
9.12725 \\
8^{* * *}\end{array}$ & $\begin{array}{c}- \\
6.37018 \\
5^{* * *} \\
\end{array}$ & $\begin{array}{c}- \\
6.30052 \\
5^{* * *} \\
\end{array}$ & $\begin{array}{c}- \\
25.3927 \\
4^{* * *} \\
\end{array}$ & $\begin{array}{c}- \\
25.2855 \\
2^{* * *} \\
\end{array}$ & $\begin{array}{c}- \\
24.9495 \\
7^{* * *} \\
\end{array}$ \\
\hline INFR & $\begin{array}{c}- \\
2.41463 \\
9^{* * *}\end{array}$ & $\begin{array}{c}- \\
2.30757 \\
5^{* * *} \\
\end{array}$ & $\begin{array}{c}- \\
2.23458 \\
7^{* * *} \\
\end{array}$ & $\begin{array}{c}- \\
5.23380 \\
3^{* * *} \\
\end{array}$ & $\begin{array}{c}- \\
5.23627 \\
0^{* * *} \\
\end{array}$ & $\begin{array}{c}- \\
5.22358 \\
9^{* * *} \\
\end{array}$ \\
\hline $\begin{array}{l}\text { PDEP } \\
\text { R }\end{array}$ & $\begin{array}{c}- \\
12.6619 \\
4^{* * *}\end{array}$ & $\begin{array}{c}- \\
12.5469 \\
1^{* * *} \\
\end{array}$ & $\begin{array}{c}- \\
12.4504 \\
9^{* * *} \\
\end{array}$ & $\begin{array}{c}- \\
15.4096 \\
6^{* * *} \\
\end{array}$ & $\begin{array}{c}- \\
15.2503 \\
7^{* * *} \\
\end{array}$ & $\begin{array}{c}- \\
15.1104 \\
4^{* * *} \\
\end{array}$ \\
\hline $\begin{array}{l}\text { GREV } \\
\text { R }\end{array}$ & $\begin{array}{c}- \\
19.4304 \\
9^{* * *}\end{array}$ & $\begin{array}{c}- \\
19.2597 \\
9^{* * *} \\
\end{array}$ & $\begin{array}{c}- \\
19.0874 \\
1^{* * *} \\
\end{array}$ & $\begin{array}{c}- \\
32.8874 \\
0^{* * *} \\
\end{array}$ & $\begin{array}{c}- \\
32.5723 \\
6^{* * *} \\
\end{array}$ & $\begin{array}{c}- \\
32.2502 \\
9^{* * *} \\
\end{array}$ \\
\hline $\begin{array}{l}\text { GEXP } \\
\text { R }\end{array}$ & $\begin{array}{c}- \\
15.0044 \\
3^{* * *}\end{array}$ & $\begin{array}{c}- \\
14.8622 \\
4^{* * *} \\
\end{array}$ & $\begin{array}{c}- \\
14.7468 \\
1^{* * *} \\
\end{array}$ & $\begin{array}{c}- \\
44.1806 \\
1^{* * *} \\
\end{array}$ & $\begin{array}{c}- \\
43.7386 \\
7^{* * *} \\
\end{array}$ & $\begin{array}{c}- \\
43.6830 \\
7^{* * *} \\
\end{array}$ \\
\hline \multicolumn{7}{|c|}{ MacKinnon Critical Values } \\
\hline$\% 1$ & $\begin{array}{c}- \\
2.60544 \\
2 \\
\end{array}$ & $\begin{array}{c}- \\
3.54820 \\
8 \\
\end{array}$ & $\begin{array}{c}- \\
4.12426 \\
5 \\
\end{array}$ & $\begin{array}{c}- \\
2.60544 \\
2 \\
\end{array}$ & $\begin{array}{c}- \\
3.54820 \\
8 \\
\end{array}$ & $\begin{array}{c}- \\
4.12426 \\
5 \\
\end{array}$ \\
\hline$\% 5$ & $\begin{array}{c}- \\
1.94654 \\
9\end{array}$ & $\begin{array}{c}- \\
2.91263 \\
1\end{array}$ & $\begin{array}{c}- \\
3.48922 \\
8\end{array}$ & $\begin{array}{c}1.94654 \\
9\end{array}$ & $\begin{array}{c}- \\
2.91263 \\
1\end{array}$ & $\begin{array}{c}- \\
3.48922 \\
8\end{array}$ \\
\hline$\% 10$ & $\begin{array}{c}- \\
1.61318 \\
1\end{array}$ & $\begin{array}{c}- \\
2.59402 \\
7 \\
\end{array}$ & $\begin{array}{c}- \\
3.17311 \\
4 \\
\end{array}$ & $\begin{array}{c}- \\
1.61318 \\
1 \\
\end{array}$ & $\begin{array}{c}- \\
2.59402 \\
7 \\
\end{array}$ & $\begin{array}{c}- \\
3.17311 \\
4 \\
\end{array}$ \\
\hline
\end{tabular}

\section{Econder $\quad$ ECONDER}


Note: ${ }^{*},{ }^{* *},{ }^{* * *}$ signs represent $.10, .05$. and .01 significance level of $(\alpha)$ critical values respectively.

The unit root test results revealed that GDP was I(0), Exchange Rate was I(1), M2 was I(0), Inflation was I(1). Due to different stationary levels of series, ARDL Bound Test was chosen and executed as the right estimation method for equation 1 (Peseran and Shin, 1999). Additionally, as for the second equation above (see equation 1), all variables were observed as stationary at level $[\mathrm{I}(0)]$. In other words, in addition to GDP, public debt, government revenue, and government expenditure were seen as stationary $[\mathrm{I}(0)]$ respectively. Also, the Least Squares (LS) method was conducted in equation 2 .

To test the monetary policies' impacts on the growth, equation 3 below was created and thereafter estimated.

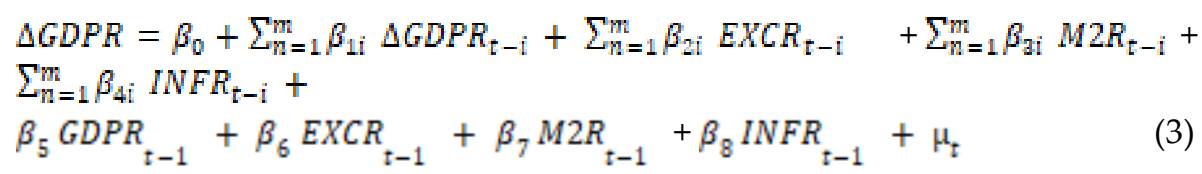

The Long-run and short-run coefficients of the variables were estimated and presented in Table 3. According to the results; there were not seen any autocorrelation, heteroscedasticity, and normality problems. Additionally, the model was observed to be set-up right. As a result, the results can be said reliable.

Table 3: Long-term and Short-term Coefficient Estimations

\begin{tabular}{|c|c|c|c|c|}
\hline \multicolumn{5}{|c|}{ Long-term Coefficient } \\
\hline Variable & Coefficient & Standart Error & t-statistics & $\begin{array}{c}\text { p- } \\
\text { value }\end{array}$ \\
\hline EXCR & -29.397482 & 7.503264 & -3.917959 & 0.0003 \\
\hline M2R & 0.115956 & 0.049838 & 2.326646 & 0.0250 \\
\hline INFR & 0.189289 & 0.048036 & 3.940549 & 0.0003 \\
\hline$\underline{\mathrm{C}}$ & 35.222924 & 8.704121 & 4.046695 & 0.0002 \\
\hline \multicolumn{5}{|c|}{ Short-term Coefficient } \\
\hline$\Delta($ GDPR(-1)) & 0.127377 & 0.129754 & 0.981680 & 0.3320 \\
\hline$\Delta($ GDPR(-2)) & 0.302405 & 0.125657 & 2.406587 & 0.0207 \\
\hline$\Delta($ GDPR(-3)) & 0.275766 & 0.107815 & 2.557766 & 0.0143 \\
\hline$\Delta(\mathrm{EXCR})$ & 25.800468 & 6.513436 & 3.961115 & 0.0003 \\
\hline$\Delta(\operatorname{EXCR}(-1))$ & 16.483365 & 7.754098 & 2.125762 & 0.0396 \\
\hline$\Delta(\operatorname{EXCR}(-2))$ & 12.836839 & 7.690445 & 2.125762 & 0.0396 \\
\hline$\Delta(\operatorname{EXCR}(-3))$ & 22.347876 & 7.538900 & 2.964342 & 0.0050 \\
\hline$\Delta$ (INFR) & 0.047041 & 0.031685 & 1.484665 & 0.1453 \\
\hline \multicolumn{5}{|c|}{ Table4: Continue } \\
\hline \multirow[t]{2}{*}{$\Delta($ INFR(-1)) } & -0.129278 & 0.032634 & -3.961419 & 0.0003 \\
\hline & \multicolumn{2}{|c|}{$\begin{array}{c}\text { ECONDER } \\
\text { International Academic Journal } \\
\text { [Issn: 2602-3806] }\end{array}$} & \multicolumn{2}{|c|}{$\begin{array}{c}\text { Cilt / Vol: } 5 \text {, } \\
\text { Sayı/Issue: } 1 \text {, } \\
2021\end{array}$} \\
\hline
\end{tabular}




\begin{tabular}{|c|c|c|c|c|}
\hline$\Delta(\mathrm{M} 2 \mathrm{R})$ & 0.047376 & 0.019420 & 2.439526 & 0.0191 \\
\hline ECM (-1) & -0.735154 & 0.123722 & -5.941994 & 0.0000 \\
\hline \multicolumn{5}{|c|}{ Table 3 (Continue) Results of Diagnostic Tests } \\
\hline $\mathrm{R}^{2}$ & 0.655787 & $X^{2} \mathrm{JB}$ & $0.779316(0.6772)$ & \\
\hline Adjusted $R^{2}$ & 0.538251 & $\mathrm{X}^{2} \mathrm{BG}$ & $0.042440(0.9585)$ & \\
\hline \multicolumn{5}{|l|}{ Table } \\
\hline F-statistics & $5.365324(0.0000)$ & $\mathrm{X}^{2}{ }_{\mathrm{BPG}}$ & $0.334532(0.9850)$ & \\
\hline DW & 2.012074 & $X^{2}$ Ramsey & $1.427901(0.1611)$ & \\
\hline
\end{tabular}

Note: $\mathrm{X}^{2} \mathrm{JB}$ represents normality, $\mathrm{X}^{2}{ }_{\mathrm{BG}}$ represents autocorrelation, $\mathrm{X}^{2} \mathrm{BPG}$ represents

heteroscedasticity and $\mathrm{X}^{2}$ Ramsey represent model set-up errors.

When the long-term coefficients are examined; It was observed that the exchange rate, M2 money supply, and inflation rate were effective on growth. Among these, the effect of the exchange rate is negative, while the effect of others is positive.

Considering short-term coefficients; the exchange rate, inflation rate, and M2 money supply seem to be effective in the short run on GDP. Based on the results of the correction model which is a large negative number, one can readily conclude that the model works properly, and the local deviations that occur are going to be stabilized in longer periods. A shock that will occur in the short term comes to balance after about 4 months.

The graphs of CUSUM and CUSUMQ (Brown et al., 1975) were developed to determine whether there is a break in the model that has been examined and the result is presented in Figure 1. As can be seen, the longterm coefficients are consistent since the residual variances at the $5 \%$ significance level do not exceed the critical limits (Tatli and Lebe, 2017:18); In other words, it is possible to state that the relationship between GDP and money supply, inflation and Exchange rate is consistent in the long run. 


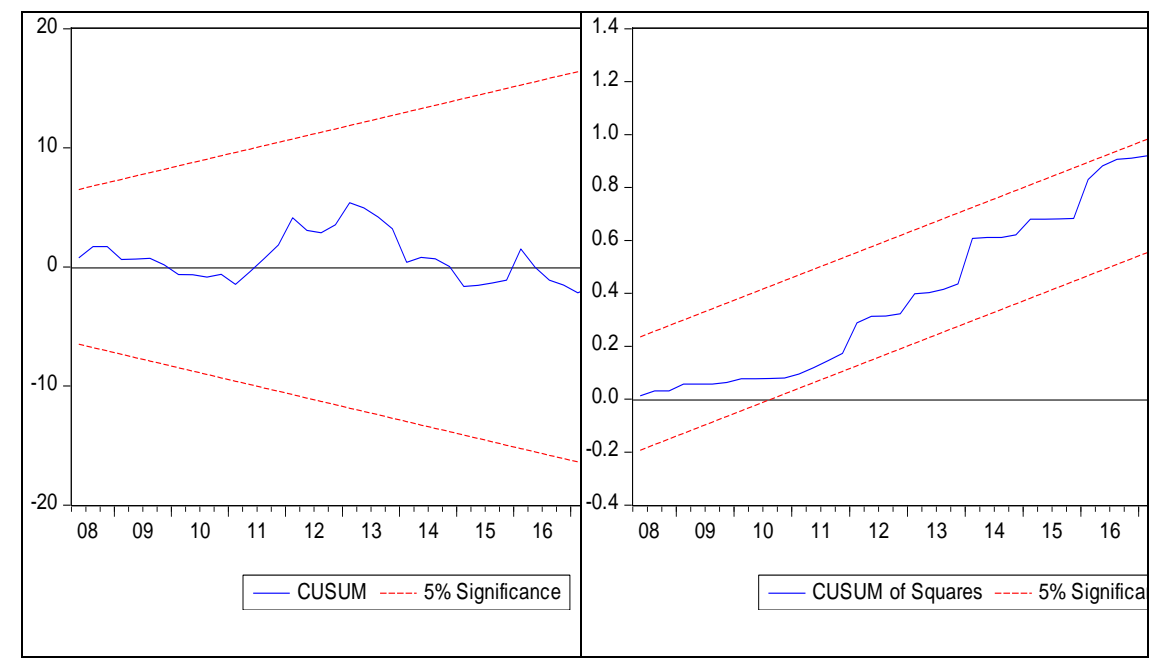

Figure 1. CUSUM and CUSUMQ Graphics

In unit root tests (see Table 1 and Table 2), it was observed that the series of public debt, public revenues, and public expenditures were stationary at level. Therefore, the effect of these variables on growth was estimated using the Ordinary Least Squares (OLS) method, and thereafter the results are presented in Table 4.

Table 4: Results of OLS Method Estimations

\begin{tabular}{|c|c|c|c|c|}
\hline Variable & Coefficient & Standart Error & t-statistics & $\begin{array}{c}\text { p- } \\
\text { value }\end{array}$ \\
\hline PDEPR & -0.062951 & 0.023915 & -2.632296 & 0.0110 \\
\hline GREVR & 0.052092 & 0.016431 & 3.778977 & 0.0004 \\
\hline GEXPR & -0.019400 & 0.153117 & -2.059487 & 0.0600 \\
\hline \multicolumn{5}{|c|}{ Results of Diagnostic Tests } \\
\hline$\overline{\mathrm{R}^{2}}$ & 0.510349 & DW & 1.231994 & \\
\hline Adjusted $\mathrm{R}^{2}$ & 0.485116 & $\mathrm{X}^{2} \mathrm{JB}$ & 1.524512( & $.7241)$ \\
\hline F-statistics & 63.22480 & $\mathrm{X}^{2} \mathrm{BG}$ & 0.260965 & 7713) \\
\hline F probability & $(0.00000)$ & $\mathrm{X}^{2} \mathrm{BPG}$ & $0.152254(C$ & 9278) \\
\hline
\end{tabular}

Note: $X^{2}{ }_{\mathrm{JB}}$ represents normality, $\mathrm{X}^{2}{ }_{\mathrm{BG}}$ represents autocorrelation, $\mathrm{X}^{2}{ }_{\mathrm{BPC}}$ represents heteroscedasticity and $X^{2}$ Ramsey represent model set-up errors.

According to the results; public debt and government expenditure have a negative effect on growth, while government revenue seems to have positive effects on growth. The signs of the variables were observed to be consistent with economic theory and economic expectations.

Moreover, there were not any observed normality, heteroscedasticity, and also autocorrelation problem in the model. All of these results of the residual diagnostic test were given just below Table 5 .

ECONDER International Academic Journal [Issn: 2602-3806]
Cilt / Vol: 5 Say1/Issue: 1 , 2021 
To clarify the short-term effects of independent variables on growth, we conducted firstly VAR model, then estimated the VEC model, and finally executed Wald Test to examine if the independent variables affect growth in the short term or not.

The optimal length lag results were presented in Table 5. As seen in Table 6 , the optimal length lag seems to be 4 .

Table 5. Optimal Length Lag

\begin{tabular}{lcccccc}
\hline Lag & LogL & LR & FPE & AIC & SC & HQ \\
\hline & & & & & & \\
0 & -980.4872 & NA & $4.15 \mathrm{e}+10$ & 35.79953 & $35.94552^{*}$ & 35.85599 \\
1 & -948.4780 & 58.19848 & $2.32 \mathrm{e}+10$ & 35.21738 & 35.94732 & 35.49966 \\
2 & -929.7186 & 31.37934 & $2.12 \mathrm{e}+10$ & 35.11704 & 36.43093 & 35.62513 \\
3 & -907.7494 & 33.55297 & $1.75 \mathrm{e}+10$ & 34.89998 & 36.79782 & 35.63389 \\
4 & -879.6472 & $38.83221^{*}$ & $1.18 \mathrm{e}+10^{*}$ & $34.45990^{*}$ & 36.94169 & $35.41963^{*}$ \\
5 & -865.2778 & 17.76572 & $1.36 \mathrm{e}+10$ & 34.51919 & 37.58494 & 35.70474 \\
\hline
\end{tabular}

The VAR stability condition test result was presented below. In Table 6 and Figure 2, appeared to be less than " 1 " and no roots lie outsides the unit circle, which means that the VAR model satisfies the stability condition.

Table 6. Optimal Length Lag

\begin{tabular}{cc}
\hline Root & Modulus \\
\hline-0.939803 & 0.939803 \\
$0.032814-0.896367 i$ & 0.896967 \\
$0.032814+0.896367 i$ & 0.896967 \\
$-0.724863-0.453485 i$ & 0.855029 \\
$-0.724863+0.453485 i$ & 0.855029 \\
$-0.374116-0.745111 i$ & 0.833759 \\
$-0.374116+0.745111 i$ & 0.833759 \\
$0.738475-0.365029 i$ & 0.823766 \\
$0.738475+0.365029 i$ & 0.823766 \\
$0.780791-0.237081 i$ & 0.815992 \\
$0.780791+0.237081 i$ & 0.815992 \\
$0.477506-0.495707 i$ & 0.688286 \\
$0.477506+0.495707 i$ & 0.688286 \\
$-0.452414-0.470703 i$ & 0.652871 \\
$-0.452414+0.470703 i$ & 0.652871 \\
0.475430 & 0.475430 \\
\hline
\end{tabular}




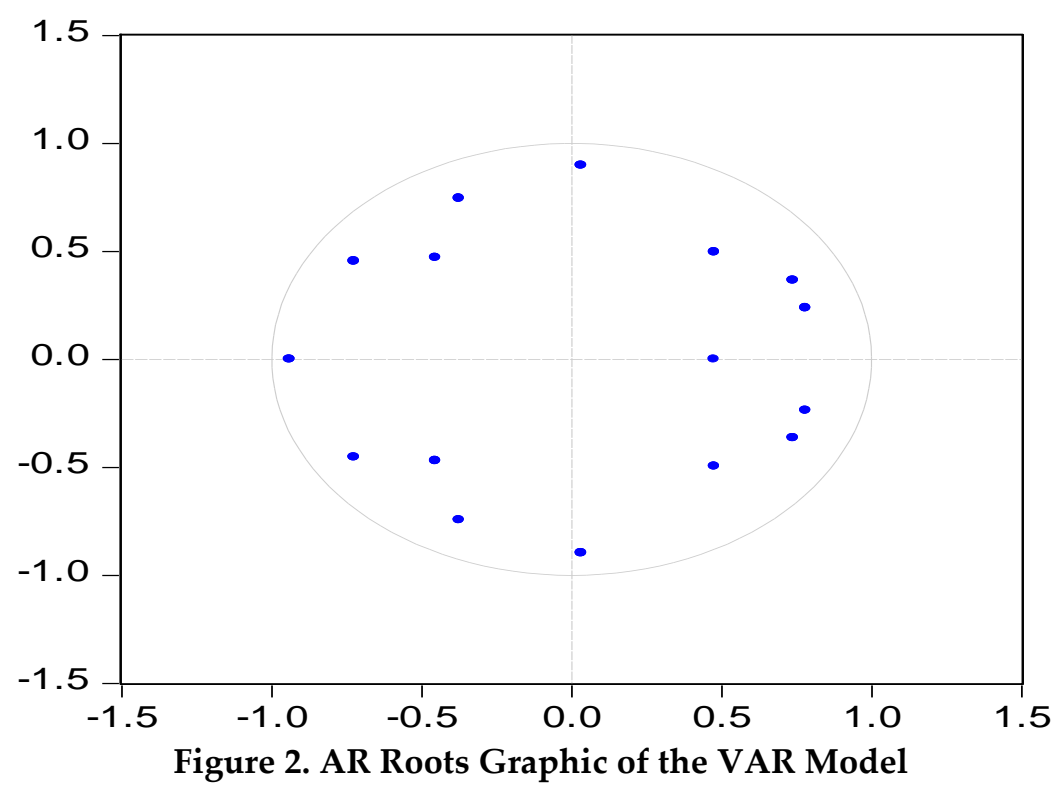

According to the VAR diagnostic Test results, there is no autocorrelation, heteroscedasticity, and normality problem in the model.

Table 7. Results of VAR Diagnostic Test

\begin{tabular}{lcll}
\hline $\mathrm{R}^{2}$ & 0.607189 & $\mathrm{X}^{2} \mathrm{JB}$ & $681.8813(0.3241)$ \\
Adjusted $\mathrm{R}^{2}$ & 0.445116 & $\mathrm{X}^{2} \mathrm{HTC}$ & $312.9190(0.4713)$ \\
F-statistics & 3.767774 & $\mathrm{X}^{2} \mathrm{LM}$ & $18.15564(0.5278)$ \\
\hline
\end{tabular}

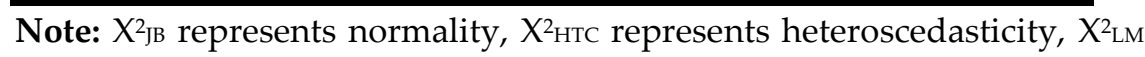
represents autocorrelation results.

The results of the VEC model are presented in Table 8. As seen in Table 8 , the coefficient of the VECM is negative and greater than " 2 " as an absolute value. This means that any shock that can take place in the shortterm may disappear in the long-term.

Table 8. Results of VECM

\begin{tabular}{ccccc}
\hline $\begin{array}{c}\text { Error } \\
\text { Correction: }\end{array}$ & D(GDPR) & D(EXPR) & D(PDEBR) & D(REVR) \\
\hline CointEq1 & -0.219675 & -6.297567 & 0.117241 & 1.568981 \\
& $(0.01506)$ & $(0.85564)$ & $(0.26107)$ & $(1.11766)$ \\
& {$[-2.30645]$} & {$[-7.36007]$} & {$[0.44908]$} & {$[1.40381]$} \\
\hline
\end{tabular}

Note: standart errors are presented in ( ) and t-statistics in [ ].

The short-term relationship among variables is presented in Table 9. According to estimation, it was put forward that the public expenditure, revenue, and debts affect the growth in the short-run. 
Table 9. Results of Short-term Relation of Variables

\begin{tabular}{lccc}
\hline Test Statistic & Value & df & Probability \\
\hline F-statistic & 0.447879 & $(1,57)$ & 0.0060 \\
Chi-square & 0.447879 & 1 & 0.0033 \\
\hline
\end{tabular}

\section{Results and Discussions}

In this study, the effects of monetary and fiscal policies on growth are examined.

In the first part of the study, the M2 money supply, inflation rate, and exchange rate are monetary policy variables. ARDL Bound Test approach was used to observe the effect of these variables on growth. As a result of the estimation, it has been observed that money supply, inflation, and exchange rate affect growth. While the effect of the Exchange rate among these effects was negative, the effects of the inflation rate and M2 money supply were positive. These results align with economic theory and some studies (Basirat et al., 2014) emphasizing that exchange rates negatively affect economic growth. Xianglan and $\mathrm{Xi}$ (2011) indicate the negative effects of the exchange rate in GDP, whereas the positive effects of M2 on GDP. Likewise, Ogunmuyiwa and Ekone 2010 assert that M2 has a positive effect on economic growth.

Some studies in the literature (Mallik and Chowdhury, 2001; Majumder, 2016; Osuala and Onyeike, 2013) assert that inflation is necessary for economic growth. Despite the analyzed findings, which indicate inflation has positive effects on GDP, one of the policies to be followed by the Central Bank is to maintain the price level to avoid large inflation rates and, at the same time, price stability positively affects economic growth.

In the second part of the study, the impact of budgetary policies on total growth is investigated. Government expenditures, government revenues, and government debt are selected as independent variables as fiscal policy tools. Variables were analyzed using the OLS method and their effects on growth were examined. According to the findings; the effects of government debt and government spending on growth were negative, while the effect of government revenues was positive. Our findings are in complete agreement with what Panizza and Presbitero published in 2013. The negative impact of public debt depends more on the composition of the public debt than on the size of the debt itself. The difference in the structure of public debt between countries is what determines its effect, whether negative or positive, as well as the purpose of the debt and the duration of its repeat. Based on the short-term investigation outcomes, public expenditure, public revenue, and public debts affect the growth in the shortrun. 
The study relied on official and real data of expenditures, revenues, and public debt of Iraq. It was found that both recurrent expenses of the government and public debt have adverse effects on economic growth in the short term. Funds are spent on salaries and social care, while these funds are not directed to productive and investment expenditures. Iraq suffers from a deficit in the infrastructure, therefore economic growth cannot be achieved. These results are supported by some studies (Devarajan et al., 1996; Rahman et al., 2019). As for the revenues, they have a positive effect since Iraq is one of the countries rich in natural resources and is dependent on about $80 \%$ of its revenues on oil. Since oil prices from 2005-2018 are on the rise, and the yields were sufficient to meet a need, as is the case in rentier countries. These results are supported by studies of Akacem et al. (2020).

\section{Limitations Of The Study And Future Implications}

As for the limitations of the study, the data used in this study are limited to the years 2005-2019. In the analysis performed, the effect of other variables on growth was accepted as constant (ceteris paribus). Therefore, these restrictions should be taken into account while generalizing the results.

Considering the suggestions for future studies, it is possible to state that the explanatory power of the study can be increased by expanding the data set both in time and in different countries in future studies.

\section{Kaynakça / Reference}

Abiola, J., and A. Moses (2018). Impact of Tax Administration on Government Revenue in a Developing Economy-A Case Study of Nigeria. International Journal of Business and Social Science Leicester Business School De Montfort University Department of Accounting and Finance Leicester, UK.

Adefeso, H.A., and H. I. Mobolaji (2010). The Fiscal-Monetary Policy and Economic Growth in Nigeria: Further Empirical Evidence, Pakistan Journal of Social Sciences, 7(2), 137-42.

Ajisafe, R.A., and B. A. Folorunso (2002). The Relative Effectiveness of Fiscal and Monetary Policy in Macroeconomic Management in Nigeria. The African Economic and Business Review, 3(1), 23-40.

Ahlborn, Markus; Schweickert, Rainer (2016). Public debt and economic growth: Economic systems matter, Econstor.cege Discussion Papers, No. 281

Akacem, M., D.D. Miller, and J.L. Faulkner (2020). Oil, Institutions, and Sustainability in MENA., Springer Nature Switzerland AG 2020.

Ali S, Fazli R, Umar H.A., and Naveed A. (2013). The composition of public expenditures and economic growth: evidence from Pakistan. International Journal of Social Economics The current issue and full-text archive of this journal is available at www.emeraldinsight.com/03068293.htm 
Alkasasbeh O.M. A., and N. . Haron (2018). Fiscal Policy and Its Relationship with Economic Growth: A Review Study, Saudi Journal of Business and Management Studies (SJBMS), 3(12), 1318-1323

Ayodeji, A., and Oluwole, A. (2018). Impact of monetary policy on economic growth in Nigeria.OpenAccess Library Journal, 5(2), 1-12.

Bain, M.K., and P. Howells (2003). Monetary Economics: Policy and Its Theoretical Basis. Macmillan International Higher Education.

Basirat, M., A. Nasirpour, and A. Jorjorzadeh (2014). The Effect of Exchange Rate Fluctuations on Economic Growth Considering the Level of Development of Financial Markets in Selected Developing Countries. Asian Economic and Financial Review, 4(4), 517-28.

Bayrak, R.(2019).Does the Optimal Size of Defense Expenditure Exist?, An Empirical Study on Turkey, The Journal of Defense Sciences, May 2019, 18(1), 135-160.

Bayrak, R. (2020). Optimal Public Expenditure in Sustainable Development, Sustainable Development: Interdiciplined Approach (Eds: Riza Bayrak and Mustafa Polat), Ankara: Nobel Publications.

Bernanke, B., Olekalns, N., and Frank, R. H. (2008). Principles of Macroeconomics. Publisher: McGraw-Hill Education/Australia.

Benhabib J. and Spiegel M.M. (2009). Moderate inflation and the deflationdepression link, Jornal of money, Credit andBanking, 41(40),787-798.

Brown, R L., J. Durbin, and J.M. Evans (1975). Techniques for Testing the Constancy of Regression Relationships over Time. Journal of the Royal Statistical Society: Series B (Methodological), 37(2),149-63.

Buyandelger, O. E. (2015). Exchange Rate Pass-through Effect and Monetary Policy in Mongolia: Small Open Economy DSGE Model. Procedia Economics and Finance, 26, 1185-92.

Çetin, M., E. Ecevit, F. Seker, and D. Günaydin (2015). Financial Development and Energy Consumption in Turkey: Empirical Evidence from Cointegration and Causality Tests., p.297-314 in Handbook of Research on Behavioral Finance and Investment Strategies: Decision Making in the Financial Industry. IGI Global.

Chen, J . (2012 ). Real Exchange Rate and Economic Growth: Evidence from Chinese Provincial Data (1992 - 2008). 2012. halshs-00667467f

Chowdhury, A. R., J. S. Fackler, and W. D. McMillin (1986). Monetary Policy, Fiscal Policy, and Investment Spending: An Empirical Analysis, Southern Economic Journal, 52(3), 794-806.

Congress.gov. H.R.8 - American Taxpayer Relief Act of 2012, https://www.congress.gov/bill/112th-congress/house-bill/8, Accessed Date: 23 September 2019.

Cornelius M. Ojong, Ogar Anthony. Oka Felix Arikpo.(2016). The Impact of Tax Revenue on Economic Growth: Evidence from Nigeria. IOSR Journal of Economics and Finance (IOSR-JEF)e-ISSN: 2321-5933, p- 
ISSN: 2321-5925.Volume 7, Issue 1. Ver. I (Jan. -Feb. 2016), PP 32-38

Cyrus, M. (2014). Monetary and Fiscal Policy Shocks and Economic Growth in Kenya: VAR Econometric Approach. Journal of World Economic Research, 3(6), 95- 108.

Dai F, and Wu. S (2013), Money supply and economic growth under environmental pressure: the strategy for re-growth. J. Monetary Economics and Finance, Vol. 6, No. 1, 2013.https://www.researchgate.net/publication/264813564.

Devarajan, S., V. Swaroop, and H. Zou (1996). The Composition of Public Expenditure and Economic Growth. Journal of Monetary Economics, 37(2), 313-44.

Dornbusch, R. Stanley, F. and Richard, S (2011). Study Guide to Accompany Dornbusch and Fischer Macroeconomics. New York: McGraw-Hill.

Lupu, D., Mihai Bogdan Petrisor, Ana Bercu, and Mihaela Tofan (2018).The Impact of Public Expenditures on Economic.Growth: A Case Study of Central and Eastern European Countries, Emerging Markets Finance and Trade, European Countries Emerging Markets Finance and Trade.ISSN: 1540-496X (Print) 1558-0938 (Online) Journal homepage: tttp://www.tandfonline.com/loi/mree20

Eichenbaum, M., Johannsen, B. K., and Rebelo, S. (2017). Monetary policy and the predictability of nominal exchange rates (No. w23158). National Bureau of Economic Research. https://www.nber.org/papers/w23158.pdf

Elliott, J. Walter. 1975. The Influence of Monetary and Fiscal Actions on Total Spending: The St. Louis Total Spending Equation Revisited. Journal of Money, Credit and Banking 7(2):181-92.

Elmendorf, D., and N. G. Mankiw. 1999. Government Debt. In J. B. Taylor and M.Business Economics National Association for Business Economics.Vol. 50, No. 4

Woodford (eds.). Handbook of Macroeconomics. Vol. 1C. Amsterdam, The Netherlands: North-Holland

Fridman, M., and D. Meiselmen (1963). The Relative Stability of Monetary Velocity and the Investment Multiplier in the United States, 1897-1958, Stabilization Policies: A series of Research Studies Prepared for the Commission on Money and Credit, Brown, E.C and Commission on Money and Credit, Eds. 1963, pp 165-268 Gujarati, D.N 2003.Basic Econometrics, New York: McGraw- Hill Companies.

Foluso A. Akinsola, Nicholas M. Odhiambo (2017). Inflation and Economic Growth: a Review of The International Literature, Comparative Economic Research, 20(3). Comparative Economic Research, Volume 20, Number 3 ,

2017

10.1515/cer-2017-0019.

Gujarati, D. N. 2003. Basic Econometrics, New York: McGraw-Hill Companies.

Gujarati, D. N., and D. Porter (2009). Basic Econometrics, Mc Graw-Hill International Edition. 
Gujarati, D. N., and D. C. Porter (1999). Essentials of Econometrics. Vol. 2. Irwin/McGraw-Hill Singapore.

Gurdal, T ., Aydin., M. Inal V.(2020 0 The relationship between tax revenue, government expenditure, and economic growth in G7 countries: new evidence from time and frequency domain approach. Economic Change and Restructuring https://doi.org/10.1007/s10644-020-09280$x$

Hameed, I., and Amen, U. (2011). Impact of Monetary Policy on Gross Domestic Product (GDP). Interdisciplinary journal of Contemporary Research in Business, 3(1), 1348-1361.

Hasanov, F (2011). Relationship Between Inflation and Economic Growth in Azerberbaijani Economy: Is There Any Threshold Effect?, Asian Journal of Business and Management Sciences, Vol. 1, No. 1, pp. 1-11, 201111 Pages Posted: 19 Sep 2011

Hasnul, Al Gifari (2015). The Effects of Government Expenditure on Economic Growth: The Case of Malaysia, MPRA Paper No. 71254

Hemming R, Michacl K., and Axel S. (2003) Fiscal Vulnerability and Financial Crises in Emerging Market Economies, Article in IMF Occasional Papers, International Monetary Fund, Publication Services 700 19th Street, N.W., Washington, D.C. 20431, U.S.A, https://www.researchgate.net/publication/5120165.

Ihsan, I., and Anjum, S. (2013). Impact of Money Supply (M2) on the GDP of Pakistan. Global Journal of Management and Business Research Finance, 13(10): 1.Publisher: Global Journals Inc. (USA)Online ISSN: 2249-4588 \& Print ISSN: 0975-5853.

Jan Jacobs, Kazuo Ogawa, Elmer Sterken, and Ichiro Tokutsu 2019. Public Debt, Economic Growth, and the Real Interest Rate: A Panel VAR Approach to EU and OECD Countries.Applied Economics. Published online: 30 Sep 2019

Jawaid, S. T., Quadri, F. S., and Ali, N. (2011). Monetary-fiscal-trade policy and economic growth Pakistan Time Seris Empirical Investigation. International Journal of Economics and Financial Issues, 1(3), 133-138.

Jeffrey M. Stupak. (2019). Fiscal Policy: Economic Effects Analyst in Macroeconomic Policy. Congressional Research Service https://crsreports.congress.gov R45723.May 16, 2019.

Joseph, F. I., and C.O. Omodero, (2020). The Nexus Between Government Revenue AND Economic Growth in NigeriaEconomics and Business ISSN 2256-0394 (online), https://content.sciendo.com, Accessed date: 06.08.2020.

Kasidi, F. Mwakanemela, K. (2013). Impact of inflation on economic growth: A case study of Tanzania, Asian Journal of Empirical Research, 3(4), 363380. http://aessweb.com/journal-detail.php?id=5004

Kasim, M.Mudhher.S. (2012). Monetary Policy of Iraq Building 
Macroeconomic Stability and Maintaining Saund Financial Regime. Deputy Governor Central Bank of Iraq Baghdad-April/2012.

Kimberly, A. (2018). Monetarism Explained with Examples, Role of Milton Friedman., https://www.thebalance.com/m onetarism-and-how-itworks-3305866, Accessed date: 02.08.2019.

Kogid, M., R. Asid, J. Lilly, D. Mulok, and N. Loganathan (2012). The Effect of Exchange Rates on Economic Growth: Empirical Testing on Nominal Versus Real, The IUP Journal of Financial Economics, 0(1), 717.

Korkmaz, S. (2013). The Effect of Exchange Rate on Economic Growth. in Conference paper Oct 2013 Bandirma onyedi Eylul University 42 Publication 165 citation.

Kumar, M. S., and J. Woo. 2010. Public Debt and Growth. IMF Working Paper WP/10/174. Washington, DC: International Monetary Fund.

Kweka, J.P. and Oliver M. (2002). Government Spending and Economic Growth in Tanzania, 1965-1996. Research Paper, No. 00/6, The University of Nottingham, Centre for Research in Economic Development and International Trade (CREDIT), Nottingham.

Majumder, S. C. (2016). Inflation and Its Impacts on Economic Growth of Bangladesh. American Journal of Marketing Research, 2(1),17-26.

Mallik, G., and A. Chowdhury (2001). Inflation and Economic Growth: Evidence from Four South Asian Countries, Asia-Pacific Development Journal, 8(1), 123-35.

Morrison, K.M. (2009). Oil, nontax revenue and the redistribution foundations of regime stability, International Organisation, 63(1), 107138.

Mourre, G, and Reut A. (2018). Non-tax revenue in the European Union: A source of fiscal risk?, Int Tax Public Finance, https://doi.org/10.1007/s10797-018-9498-z Springer Science+Business Media, LLC, part of Springer Nature.

Mugableh, M. I. (2019). Fiscal Policy Tools and Economic Growth in Jordan: Evidence from Time-Series Models, International Journal of Economics and Finance, 11(1), 1-7.

Muhammad, S.D., S.K.A. Wasti, A. Hussain, and I. Lal (2009). An Empirical Investigation between Money Supply Government Expenditure, Output \& Prices: The Pakistan Evidence, European Journal of Economics, Finance, and Administrative Sciences, (17), 60-68. ISSN 1450-2887 Issue 17 (2009) EuroJournals, Inc. 2009 http://www.eurojournals.com.

Newbold, P., and C. W. J. Granger (1974). Spurious Regressions in Econometrics. Journal of Econometrics, 2(2),111-120.

Nkoro, E., and A. K. Uko (2016). Autoregressive Distributed Lag (ARDL) Cointegration Technique: Application and Interpretation., Journal of Statistical and Econometric Methods, 5(4), 63-91.

Nurudeen, A., \& Usman, A. (2010). Government Expenditure and Economic Growth in Nigeria1970-2008: A Disaggregated Analysis. Business and 
Economics Journal, 1-11.

Nyasha S. and M. Nicholas (2019). The Impact of Public Expenditure on Economic Growth: A review of International Literature, Folia Oeconomica Stetinensia 19(2),

Ogbole F.O., S.N. Amadi ana I.D. Essi (2011). Fiscal policy: Its impact on economic growth in Nigeria Journal of Economics and International Finance, 3(6), 407-417.

Ogunmuyiwa, M. S., and A. F. Ekone (2010). Money Supply-Economic Growth Nexus in Nigeria, Journal of Social Sciences, 22(3), 199-204.

Omodero, C. O. (2019). Effect of money supply on economic growth: A comparative study of Nigeria and Ghana", International Journal of Social Science Studies, 7, 16-23.

Onuorah, A. C, and Akujuobi, L.E. 2012.Empirical Analysis of Public Expenditure and Economic Growth of Nigeria. Arabian Journal of Business and Management Review (OMAN Chapter), 1(11), Vol.1.Na.11.June 2012.

Osuala, A. E., K. I. Osuala, and S. C. Onyeike (2013). Impact of Inflation on Economic Growth in Nigeria-A Causality Test, Journal of Research in National Development, 11(1), 206-16.

Panizza, U., and A. F. Presbitero (2013). Public Debt and Economic Growth in Advanced Economies: A Survey. Swiss Journal of Economics and Statistics, 149(2),175-204.

Paul C., R. Van Der Ploeg, M. Spence, and Anthony J. Venables (2010). Managing Resource Revenues in Developing Economies, IMF Staff Papers, 57(1), International Monetary Fund

Pesaran, M. H., Y. Shin, and R. P. Smith. (1999). Pooled Mean Group Estimation of Dynamic Heterogeneous Panels. Journal of the American Statistical Association, 94(446), 621-34.

Prasert, C., Kanchana, C., Chukiat, C., \& Monekeo, K. (2015). Money supply influencing on Economic growth wide phenomena of AEC open region, Procedia Economics and Finance, 24(2015), 108-115. https://doi.org/1016/S2212-5671(15)00626-7.

Puig, M,G. (2013). Public debt and economic growth: Further evidence for the euro area. Risckcenter Research group-IREA. Av. Diagonal 696; 08034 Barcelona,Spain

Rahman, M. H. (2005). Relative Effectiveness of Monetary and Fiscal Policies on Output Growth in Bangladesh: A VAR Approach, Policy Analysis Unit Bangladesh Working Paper WP0601.

Rahman, N. H. A., S. Ismail and A. R. Ridzuan (2019). How Does Public Debt Affect Economic Growth? A Systematic Review,Cogent Business $\mathcal{E}$ Management, 6(1),1701-339. https://doi.org/10.1080/23311975.2019.1701339.

Rapach D.E. (2003), International evidence on the long-run impact of inflation, 
'Journal of Money Credit, and Banking,35(1),23-48.

Reinhart, Carmen M., Kenneth S. Rogoff.Growth in a Time of Debt. National Bureau of Economic Research 1050 Massachusetts Avenue Cambridge, MA $02138 \quad$ January. Working $\quad 15639$ http://www.nber.org/papers/w15639.

Riyadh, M. Lubis, G. Abdul, N, K (2017). Exchange Rate Effect on Gross Domestic Product in the Five Founding Members of ASEAN, International Journal of Academic Research in Business and Social Sciences, 7(11), ISSN: 2222-6990

Senbet, D. (2011). The Relative Impact of Fiscal versus Monetary Actions on Output: A Vector Autoregressive (VAR) Approach, Business and Economics Journal, 25, 1-11

Sheilla Nyasha and Nicholas M. Odhiambo. 2019. The Impact of Public Expenditure on Economic Growth: A Review of International Literature. Folia Oeconomica Stetinensia Volume 19 (2019) Issue 2

Shrestha, M. B., and G. R. Bhatta (2018). Selecting appropriate methodological framework, The Journal of Finance and Data Science, 4(2), 71-89. Received 1 July 2017; revised 3 November 2017; accepted 6 November 2017 Available online 14 February 2018.

Tatli, H., and F. Lebe (2017). The Relationship of Naturalgas Consumption, Capital and Employment with Economic Growth in Turkey: Cointegration and Causality Analysis, Izmir Journal of Economics, 32(1), $1-28$.

Three, Chapter. (2020). Fiscal Restraint in the Budget Process. 35-42. Received 1 July 2017; revised 3 November 2017; accepted 6 November 2017 Available online 14 February 2018

Trotman-Dickenson, D. I. (1996). Fiscal Policy in Relation to Economic Growth and the Standard of Living p. 452-58 in Economics of the Public Sector. by the Copyright Licensing Agency, 90 Tottenham Court Road, London W1P 9HE.

Tule M. K, Samuel F. O, Godday. U.E (2020). Monetary and fiscal policy mix in a small open economy: Evidence from Nigeria Elsevier Business District, P.M.B. 0187, Garki, Abuja, Nigeria.

Twinoburyo, E. N., \& Odhiambo, N. M. (2017). Monetary policy and economic growth: A review Of International Literature. Journal of Central Banking Theory and Practice, 2, 123-137.

Ufoeze, L. O., S. O. Odimgbe, V. N. Ezeabalisi, and U. B. Alajekwu (2018). Effect of Monetary Policy on Economic Growth in Nigeria: An Empirical Investigation, Annals of Spiru Haret University, Economic Series, 9(1),123-40.

Wai, U. T, (1995) The Relation between Inflation and Economic Development: A Statistical Inductive Study, IMF Staff Papers, 7, 302-317

Xianglan, M., and L. Xi (2011). The Research of Relationship among Money Supply and Economic Growth and the Price in China [J], Statistical Research 3, 65, 232-244. 
Zdaniuk, B (2014). Ordinary Least-Squares (OLS) Model. Netherland: Springer, Zengin, G., A. Aktumsek, R. Ceylan, S. Uysal, A. Mocan, G. O. Guler, M. F. Mahomoodally, J. Glamočlija, A. Ćirić, and M. Soković (2017). Shedding Light on the Biological and Chemical Fingerprints of Three Achillea Species (A. Biebersteinii, A. Millefolium, and A. Teretifolia), Food E Function, 8(3),1152-65. 